\title{
Quantitative morphological analysis of the sensory epithelium of the starling and pigeon basilar papilla
}

\author{
Otto Gleich and Geoffrey A. Manley \\ Institut für Zoologie der Technischen Universität München, Garching, F.R.G.
}

(Received 14 September 1987; accepted 24 February 1988)

\begin{abstract}
Several features of bird basilar papilla morphology were quantitatively studied in the starling and the pigeon in order to attempt a structure-function correlation. We confirmed and quantified several findings from earlier studies, but also obtained results contradictory to previous reports. The greatest discrepancies concerned the pattern of hair cell orientation. By including the results from other investigations, we describe a 'typical' avian basilar papilla and on this basis the specializations within individual species. These morphological specializations are discussed in the context of the available physiological data.
\end{abstract}

Bird; Basilar papilla; Morphology; Hair cell; Stereovilli

\section{Introduction}

One approach to elucidating basic mechanisms of vertebrate hearing is the comparative investigation of the different types of hearing organs that developed during vertebrate evolution. A knowledge of the morphological substrate is a prerequisite to the interpretation of physiological results. The number of physiological and anatomical studies of the bird's auditory system has increased greatly over the last 10 years. After early descriptions of the avian inner ear by Retzius (1884) and Held (1926), a detailed comparative investigation of the gross anatomy of different avian cochleae was published by Schwartzkopff and Winter (1960). Studies of fine and ultrastructural features and innervation patterns of the basilar papilla of a variety of avian species followed (Takasaka and Smith, 1971; Rosenhall, 1971; Hirokawa, 1978; Tanaka and Smith, 1978; Firbas and Müller, 1983; Tilney and Saunders, 1983; Chandler, 1984; Düring et al., 1985; Smith et al., 1985; Counter

Correspondence to: Geoffrey A. Manley, Institut für Zoologie der Technischen Universität München, Lichtenbergstrasse 4, 8046 Garching, F.R.G. and Tsao, 1986; Tilney et al., 1987). Although these studies provide a lot of detailed information, most of them are qualitative, making direct comparisons of different species difficult. Starting from this data base, we investigated the auditory epithelia of the starling and the pigeon and quantified a number of gradients over the width and length of the papillae. These results allow objective comparisons of specific morphological features between species, and thus lay the foundation for a structure-function analysis.

\section{Material and Methods}

The cochleae of adult starlings (Sturnus vulgaris) and pigeons (Columba livia dom.) were the focus of this detailed study. One adult budgerigar (Melopsittacus undulatus) and one adult chicken (Gallus gallus dom.) basilar papilla were also investigated, but not in detail. Starlings, pigeons and one budgerigar were anesthetized by injection of a $6 \%$ solution of Na-Pentobarbital into the pectoral muscle (100 $\mathrm{mg}$ per $\mathrm{kg}$ body weight). The birds were either fixed by transcardial perfusion immediately after sufficient anesthesia (normally within $10 \mathrm{~min}$; pigeons and budgerigar) or, following a neurophysiological ex- 
periment, after up to five hours (starlings) of anesthesia, including additional doses. The perfusion was performed via a cannula inserted into the left ventricle of the exposed heart and a hole cut into the right atrium. Before perfusion with the fixative ( $2.5 \%$ glutaraldehyde in $0.1 \mathrm{M}$ phosphate or cacodylate buffer, pH 7.4), the blood was washed out by $40 \mathrm{ml}$ (starlings and budgerigar) or about $100 \mathrm{ml}$ (pigcons) heparinized saline $(0.9 \%$ $\mathrm{NaCl}$ ) or a Ringer's solution (containing $116 \mathrm{mM}$ $\mathrm{NaCl}, 2.3 \mathrm{mM} \mathrm{KCl}, 29.2 \mathrm{mM} \mathrm{NaHCO}, 2.1 \mathrm{mM}$ $\mathrm{MgCl}_{2}$, and $5.8 \mathrm{ml} \mathrm{CaCl}, \mathrm{pH} \mathrm{7.4).} \mathrm{This} \mathrm{was}$ followed by $300 \mathrm{ml}$ (starlings and budgerigar) or $500 \mathrm{ml}$ (pigeons) of the fixative. The perfusion was completed within 15-30 min. The cochleae (in starlings only the cochlea contralateral to the recordings) were then exposed by removing overlying skin, muscles and bone from the caudo-lateral skull. The round window membrane and the columellar footplate were removed to enable free access of the fixative. One adult chicken was decapitated and the ventro-caudal part of the skull including the complete inner ear placed in fixative; due to hard and extensive bone it was not possible to gain rapid access to the columella and round window at the beginning of the fixation, so that preservation was poor compared to the other papillae. The specimens were then placed in fixative and kept in the refrigerator for $12 \mathrm{~h}$ to six days. Thereafter the bone overlying the basilar papilla, or the whole otic capsule enclosing the cochlear partition, ganglion and nerve were carefully removed using forceps, without decalcification. In specimens where the surface of the basilar papilla was investigated, the tegmentum vasculosum and the tectorial membrane were also removed with the help of fine forceps and needles. After the final dissection, the specimens were dehydrated in a graded series of isopropanol. Preparations for SEM were finally soaked in three portions of pure ethanol, critical point dried in $\mathrm{CO}_{2}$ (Balzers Union, CPD 020), sputter coated with a $300 \AA$ gold layer (Polaron Equipment Ltd SEM Coating Unit E 5000) and studied with a Jeol JSM-C 25 S SEM. Specimens for light microscopy were transferred to acetone and embedded in Spurr's resin. Sections, $15 \mu \mathrm{m}$ thick, were cut on a standard microtome, mounted on slides, stained in a solution containing $1 \%$ tolui- dine blue and $1 \%$ boric acid for $2 \mathrm{~min}$ at $50^{\circ} \mathrm{C}$ and covered with Depex and a coverslip.

The exact calibration of the magnification is essential for this kind of analysis and included all steps influencing the final magnification (e.g. working distance of the SEM, photographic enlargement). Photographic reconstructions of the SEM specimens (with the papilla adjusted for viewing the surface perpendicularly and final magnifications between $100 \times-1730 \times$ ) were used to divide the sensory epithelium into eleven segments along its length. The segment borders were adjusted to be perpendicular to the abneural edge of the basilar papilla at each location. A line connecting the most apical tip of the papilla, the midpoint of the segment borders and the most basal tip was used to measure the length of the whole papilla. The length of the segment borders within the neural and abneural ends of the sensory epithelium was taken as a measure of the width of the papilla. The number of hair cells was counted three times for each specimen from photographs (magnification $350 \times-1730 \times$ ) and the average of these three counts (difference less than 1\%) was taken as the number of hair cells of an individual papilla.

Using the reconstruction described above, an area $33 \mu \mathrm{m}$ to the left and right of each segment border was selected and reconstructed with photographs at magnifications of $1650 \times-2500 \times$, so that finally ten $66 \mu \mathrm{m}$-wide areas, almost equally spaced along the papilla, were reconstructed in high magnification. Fig. 1a illustrates in an outline of a pigeon papilla the line used to measure the length of the papilla and the areas where hair cell parameters were studied in detail. The number of hair cells over the width of the basilar papilla was counted along the segment border in these reconstructions. This measurement is influenced by the subjective decision of whether or not to include a certain cell that just touched the border. Due to the irregular shape of the cells, we did not apply any objectively defined criterion but included only cells that were hit 'close' to their center. Repeated counts by different persons, however, produced differences of only ten percent or less.

From the high power reconstructions, it was possible to determine the orientation of the stereovillar bundles of individual hair cells (according to 
the gradual change of the villi height within one bundle). Kinocilia were visible in very few cells and thus could not be systematically used for determining the orientation. The ten areas were subdivided into 16.5 to $18.2 \mu \mathrm{m}$-wide strips parallel to the abneural and neural ends of the epithelium. Most of the strips contained between 10 and 30 hair cells and each area consisted of 2 (base) to 19 (apex) strips. Abneural orientation of a bundle (perpendicular to the neural edge of the epithelium) was defined as zero degrees, orientations with the tallest stereovilli towards the apex were taken as positive and those towards the base as negative. The mean angle of all cells within each strip was calculated.

Three to five neighbouring hair cells from each area were selected at the most neural, middle and the most abneural position of the papilla. They were photographed at magnifications between $2100 \times-4850 \times$. The number of stereovilli was counted in these cells and averaged for neural, middle and abneural positions in each area. The cell surface and the surface covered by the base of the stereovillar bundle were measured in these same hair cells. The outlines of the cell and the base of the stereovillar bundle were copied from the photos onto a transparent sheet, together with a calibration bar. Cell surface areas were measured either by mounting the foil on graph paper and determining the area included by the outlines or by means of a graphic tablet and an appropriate computer program. Both methods yielded essentially the same results and did not vary systematically as tested in a number of cells. The average area of the three to five cells measured in neural, middle and abneural positions was then calculated.

The diameter of the stereovilli differed substantially within one bundle and even along a single villus; the tip of the villus was usually bulbed, while the villi were thin at their base. As a first approximation, the area covered by a single villus was calculated as the ratio of the cell surface covered by the whole bundle to the number of the villi within this bundle (average of three to five cells). The diameter of a single villus was then estimated to be the square-root of the corresponding surface.

The heights of stereovilli were determined from
$15 \mu$ m-thick cross sections of the cochlear duct. They were viewed with a microscope (ReichertCambridge Instruments Polyvar) using a $100 \times$ lens and differential interference contrast illumination via a video camera (Hamamatsu Photonic Microscopy System C 1966) on a TV-screen. The final magnification was 17800 and made it possible to focus on individual villi. Complete bundles within the section were selected and the longest villus of a bundle measured. For bundles that were not completely in the focal plane of the system, the distance between the focal planes of the villus' top and base had to be considered in order to determine the correct height. All complete bundles within one cross section were measured successively from the neural to the abneural side. Cells with deformed bundles were not included. In some cases it was difficult to distinguish exactly between the end of the villus and extensions from the tectorial membrane.

The same sections as used for measuring the height of the stereovillar bundles were also used for measuring the cross-sectional areas of the basilar papilla, basilar membrane and tectorial membrane. Transverse sections along the papilla separated by $75 \mu \mathrm{m}$ were drawn to magnification of $340 \times$ and the areas measured using a digitizing tablet, as described for measurement of cell surface areas.

To display data pooled from different specimens, a summary of the scatterplots was obtained using a robust locally-weighted regression and smoothing procedure (Cleveland, 1979). All smoothed plots were calculated with default values suggested in the original paper and using a low smoothing factor $(0.3$ on a scale between 0.2 and 0.8 ) to preserve details of the data distributions.

\section{Results}

Inner ears of three pigeons, four starlings, one chicken and one budgerigar were investigated. The number of hair cells was counted in three starling papillae (ranging from 5753 to 5979 with an average of 5830) and in two pigeon papillae (9050 and 10174 with an average of 9610). The average length of four starling papillae was $2.21 \mathrm{~mm}$ (range: 2.09 to $2.36 \mathrm{~mm}$ ), $3.13 \mathrm{~mm}$ (range: 2.73 to $3.52 \mathrm{~mm}$ ) 


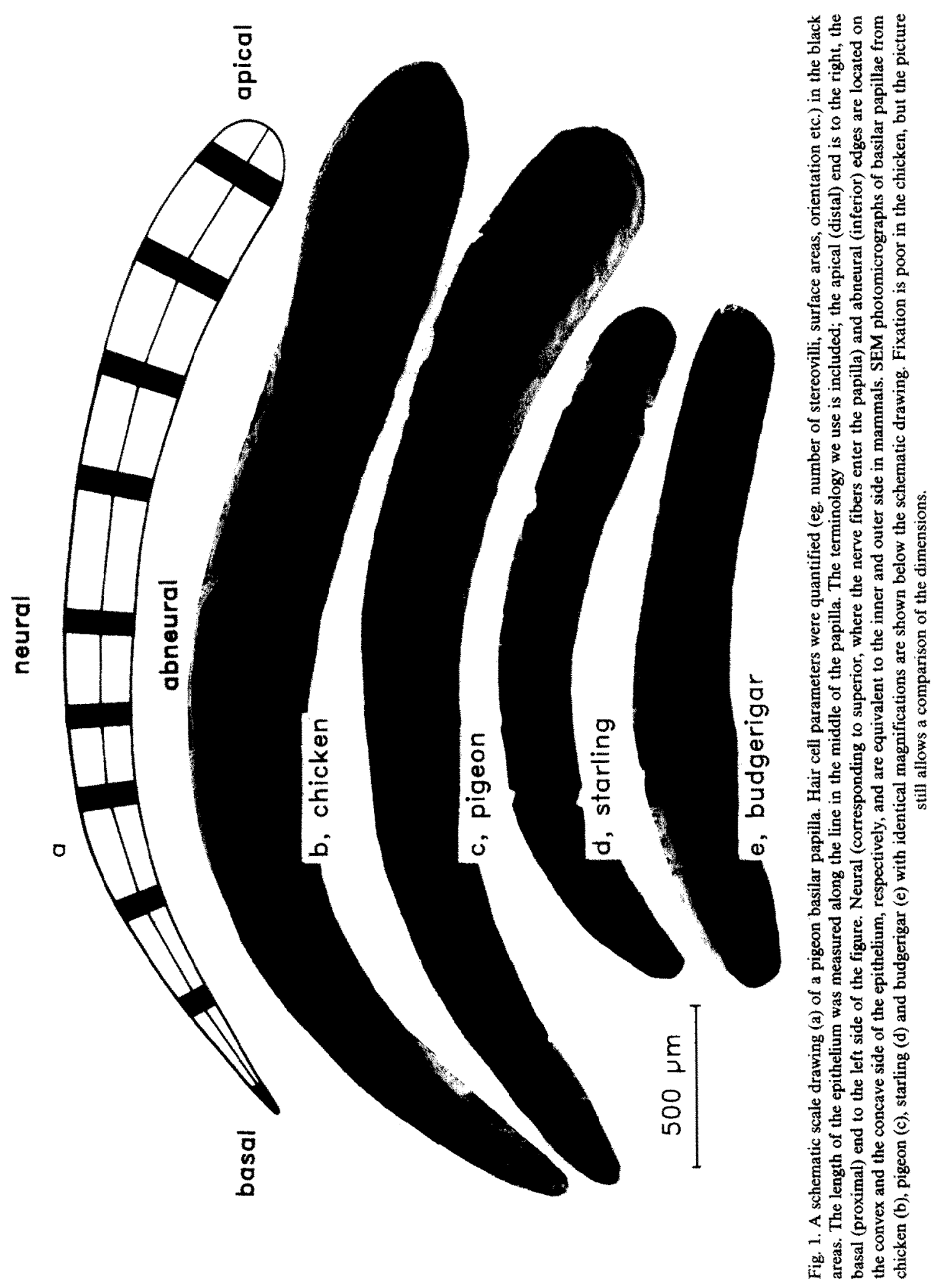


for three pigeon papillae, $3.67 \mathrm{~mm}$ in the chicken and $2.02 \mathrm{~mm}$ in the budgerigar. The starling cochleae were very similar to each other with respect to hair cell number and length of the basilar papilla, while the pigeons showed more substantial individual differences. The SEM reconstructions in Fig. 1b-e (using identical magnification) illustrate the different dimensions of the papillae in the various species.

The width of the sensory epithelium increases gradually from the base to the apex. At the most apical end, the width decreases again rather rapidly (Fig. 1c, d). A quantitative analysis of the basilar papilla's width was carried out in four starling and three pigeon cochleae, plotting the distance from the basal end as a percentage of the total length of an individual papilla. In the starlings, the width increases steadily from about $40 \mu \mathrm{m}$ at the base to $190 \mu \mathrm{m}$ at $85 \%$ of the papillar length and tapers
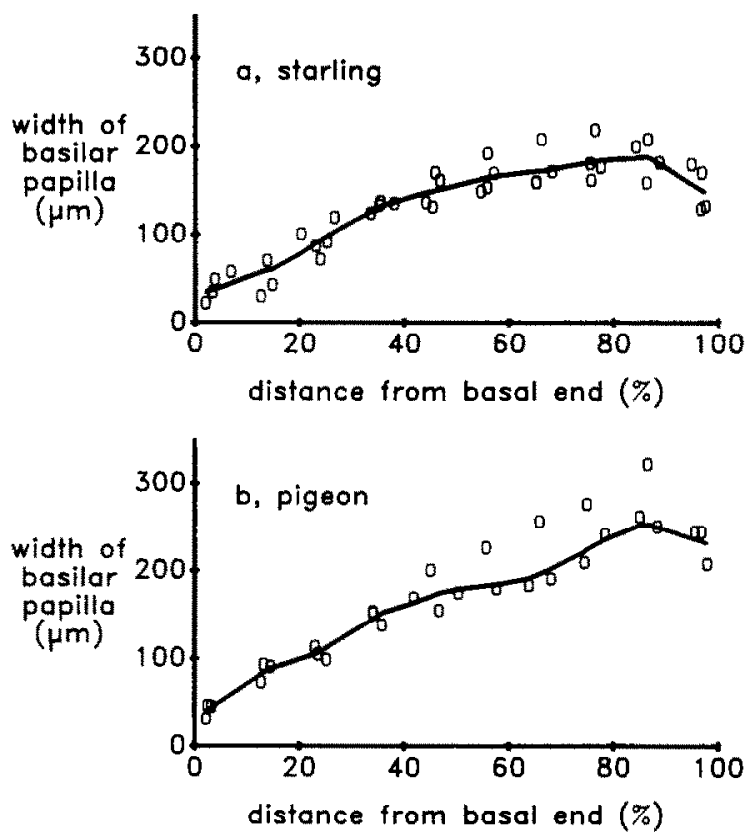

Fig. 2. Basilar papilla width as a function of the distance from the basal end. In the starling (a) the width increases almost continuously from the base to the apex and decreases again in the most apical $10 \%$ of the papilla. The increase in width in the basal two thirds of the epithelium in the pigeon (b) is similar to that of the starling. In the apical third the width increases rather rapidly in the pigeon, as compared to the starling. Open symbols represent data points, the lines in this and later figures are smoothed locally weighted regressions (Cleveland, 1979).
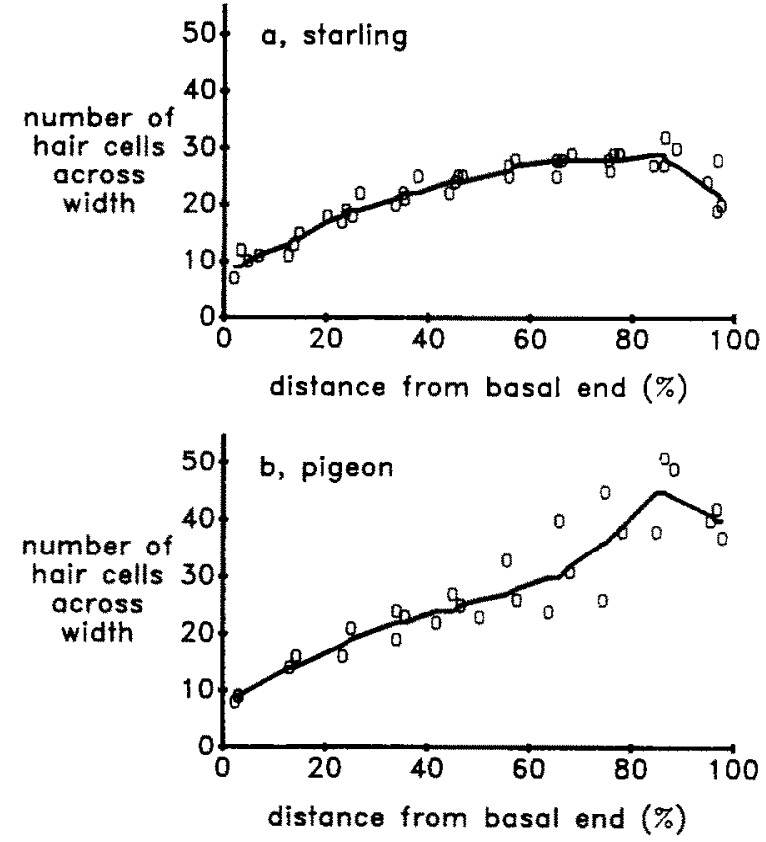

Fig. 3. Number of hair cells in a cross section as a function of position on the papilla. In the starling (a), the number of hair cells increases continuously from the base to the apex and decreases again in the most apical $10 \%$ of the papilla. The increase of hair cell number in pigeons (b) is similar to the starling in the basal two thirds of the papilla. In the apical third of the pigeon papilla, however, the number of hair cells in a cross section increases dramatically.

beyond that point (Fig. 2a). In pigeons, the width of the papilla is also $40 \mu \mathrm{m}$ at the basal end. In the apical third, however, the width increases greatly from about $190 \mu \mathrm{m}$ at $70 \%$ distance from the base up to $250 \mu \mathrm{m}$ at $90 \%$ (Fig. 2b).

The number of hair cells across the width of the papilla increases steadily in the starling (Fig. 3a, four cochleae) and pigeon (Fig. 3b, three cochleae) from about eight at the basal end to almost 30 at two thirds of the papilla length. In starlings, this number remains constant until $85 \%$ from the basal end, and decreases beyond this. In pigeons, however, the number of hair cells in one transect increases greatly from 30 at $65 \%$ to almost 50 at $90 \%$ from the basal end.

The number of stereovilli of individual hair cells gradually decreases from about 200 at the base to about 50 at the apex in both species. Fig. 4 shows data from two starling (a) and two pigeon (b) papillae. There is a tendency for the neural 

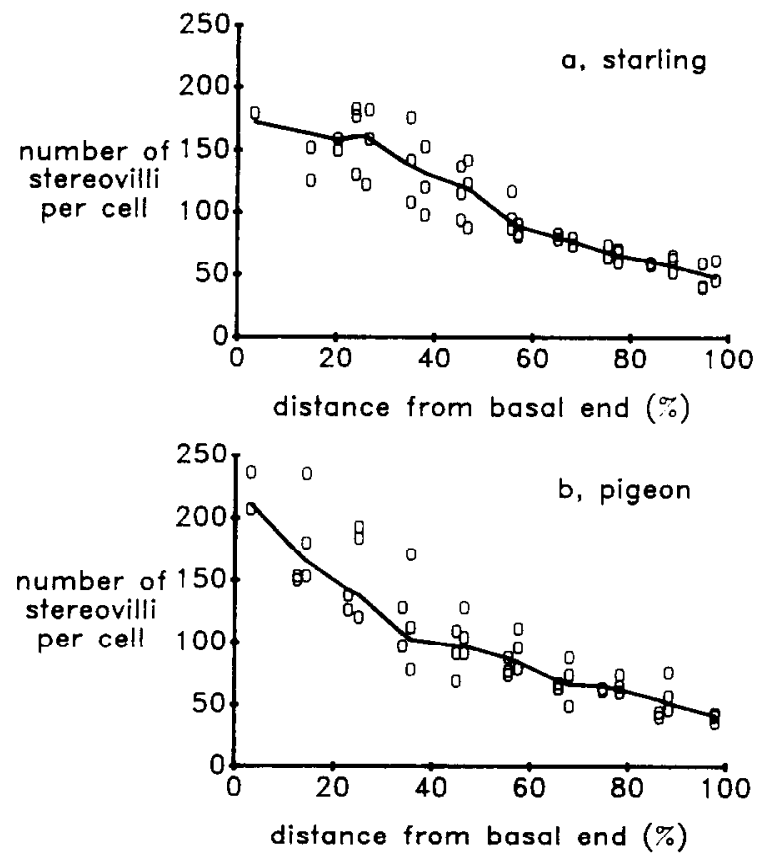

Fig. 4. Number of stereovilli per hair cell as a function of the position on the basilar papilla. The number of stereovilli decreases in starling (a) and pigeon (b) from near 200 at the basal end to 50 at the apical end (for linear regression of (a) $N=53, R=-0.91, P<0.001$; for (b) $N=49, R=-0.88$,

$$
P<0.001) \text {. }
$$

cells to have slightly more stereovilli than abneural cells.

The area of the apical surface of a hair cell differs according to the cell's position on the papilla (Fig. 5). This is illustrated for two starling cochleae in Fig. $6 \mathrm{a}$ and for two pigeons in Fig. $6 \mathrm{~b}$. The hair-cell surface area is 30 to $40 \mu \mathrm{m}^{2}$ at both the basal and apical ends of the specimens and varies little along the basilar papilla for the neural position. For abneural hair cells, however, the area is two to three times larger at about $50 \%$ of the papillar length compared to the basal and apical ends. The maximal cell surface area in starlings $\left(80 \mu \mathrm{m}^{2}\right)$ is smaller than that of pigeons $\left(120 \mu \mathrm{m}^{2}\right.$; Fig. 6a, b). A comparison of that part of the surface area of a hair cell occupied by the stereovillar bundle in the starling and pigeon (Fig. 7a, b) demonstrates that there is a decrease from the base to the apex, which is much more prominent in pigeons (18 to $4 \mu \mathrm{m}^{2}$ ) than in starlings (11 to 6 $\left.\mu \mathrm{m}^{2}\right)$.
The number of stereovilli within a single bundle and the surface area occupied by the bundle were determined in the same cells, making it possible to calculate the villus diameter (Fig. 8). We did not find significant differences between neural and abneural positions. A comparison of starling (Fig. 8a) and pigeon data (Fig. 8b), however, reveals a species' difference. The villus diameter

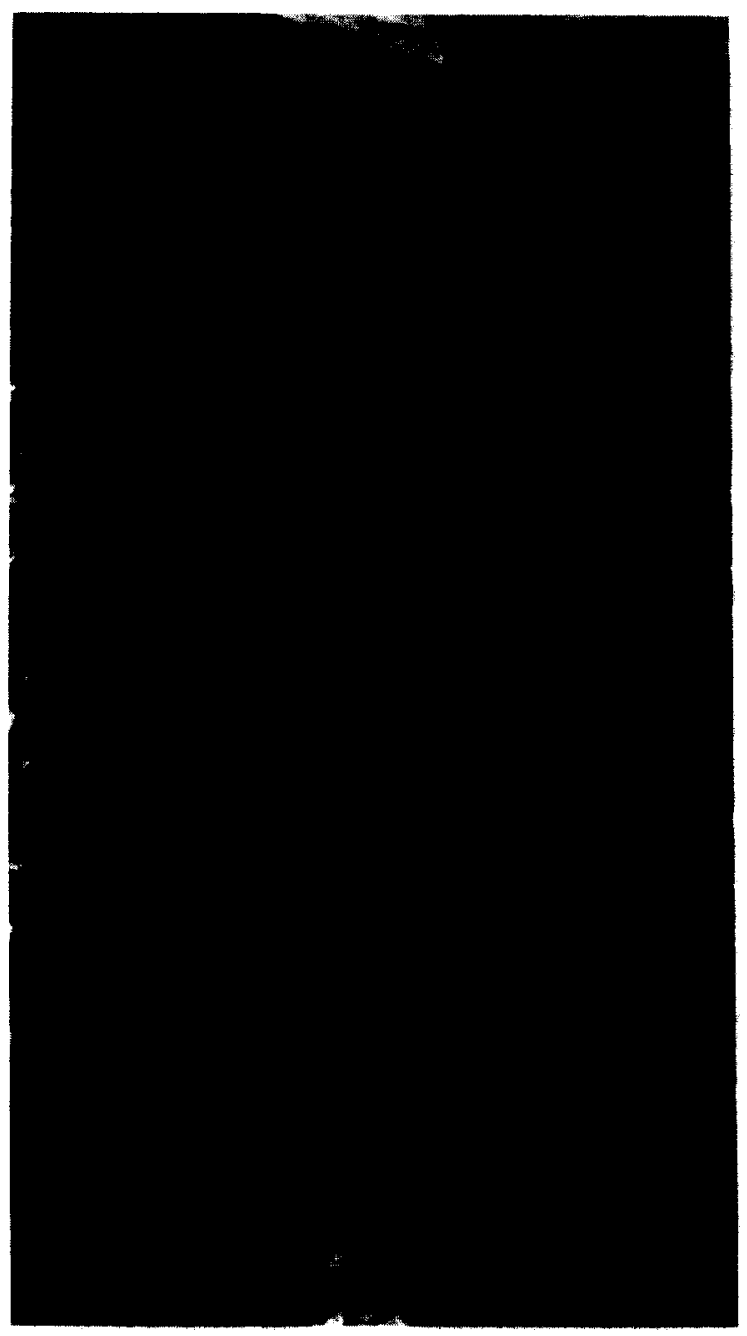

Fig. 5. SEM photomicrograph of a starling's basilar papilla at about $65 \%$ from the basal end (calibration bar corresponds to $50 \mu \mathrm{m}$ ). The increase of hair cell surface from the neural end (top) to the abneural end (bottom) is obvious. The photograph also demonstrates the gradual change of hair cell orientation over the width of the basilar papilla, with hair cells in the middle between the neural and the abneural ends rotated maximally towards the apex (right). 

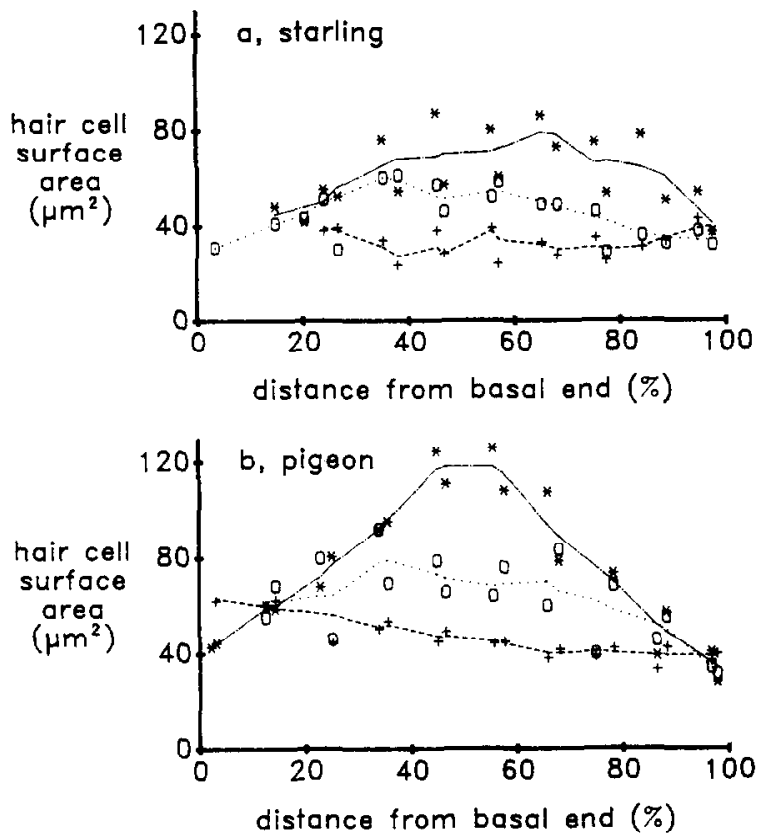

Fig. 6. Hair cell apical surface area as a function of position on the basilar papilla. The surface area of hair cells located on the neural side of the epithelium (+) varies only little, if at all, over the length of the papilla in starling (a) and pigeon (b). Hair cells located on the abneural side (*) at around $50 \%$ of the papillar length have a 2-3 times greater surface compared to those at the basal and apical ends. Hair cells located in the middle between neural and abneural side $(0)$ display an intermediate apical surface. Hair cell surface tends to be greater in the pigeon (b) than in the starling (a) and the increase of surface in abneurally located hair cells in the middle of the papilla is more pronounced in the pigeon than in the starling.

increases in the starling from $0.25 \mu \mathrm{m}$ at the base to $0.35 \mu \mathrm{m}$ at the apex of the papilla (Fig. 8a), while it is almost constant $(0.3 \mu \mathrm{m})$ over the entire length of the pigeon papilla (Fig. $8 \mathrm{~b}$ ).

The shape of the stereovillar bundles as viewed perpendicular to the papillar surface changes gradually from the basal to the apical end. This change in shape was analyzed systematically by measuring the long and the short axes of the bundles. The long axis of the bundles decreases (independent of the position over the width of the papilla) in starlings from about $7 \mu \mathrm{m}$ near the papilla base to below $4 \mu \mathrm{m}$ at the apex (Fig. 9a, data from two ears) and in pigeons from about 8 $\mu \mathrm{m}$ to $3 \mu \mathrm{m}$ (Fig. 9b, data from two ears). The short axis is less consistent between the species and shows a slight tendency to increase from the base to the apex in starlings, while it tends to decrease in pigeons (Fig. 9c, d). The ratio of the long axis to the short axis indicates the symmetry of the stereovillar bundle. A ratio of one indicates square or circular bundles, higher numbers elongated bundles. The long axis of the bundle in starlings is almost five times the short axis near the cochlear base; the ratio decreases to about 1.5 at the apex (Fig. 10a). The asymmetry in pigeons is less prominent, the ratio decreasing from about 3.5 near the base to 1.5 at the apex (Fig. 10b).

In order to determine if 'lenticular' hair cells (which differ from 'short' hair cells with respect to the location of the stereovillar bundle within the apical hair cell surface; Smith et al., 1985) are present in the two species, we measured the distance of the stereovillar bundle from the hair cell border (in the direction of the hair cell orientation). This measure ( $2 \mu \mathrm{m}$ in starlings and 2.5 $\mu \mathrm{m}$ in pigeons) does not show systematic variation over the length and width of the papillae (Fig. 11a starling, Fig. 11b pigeon).
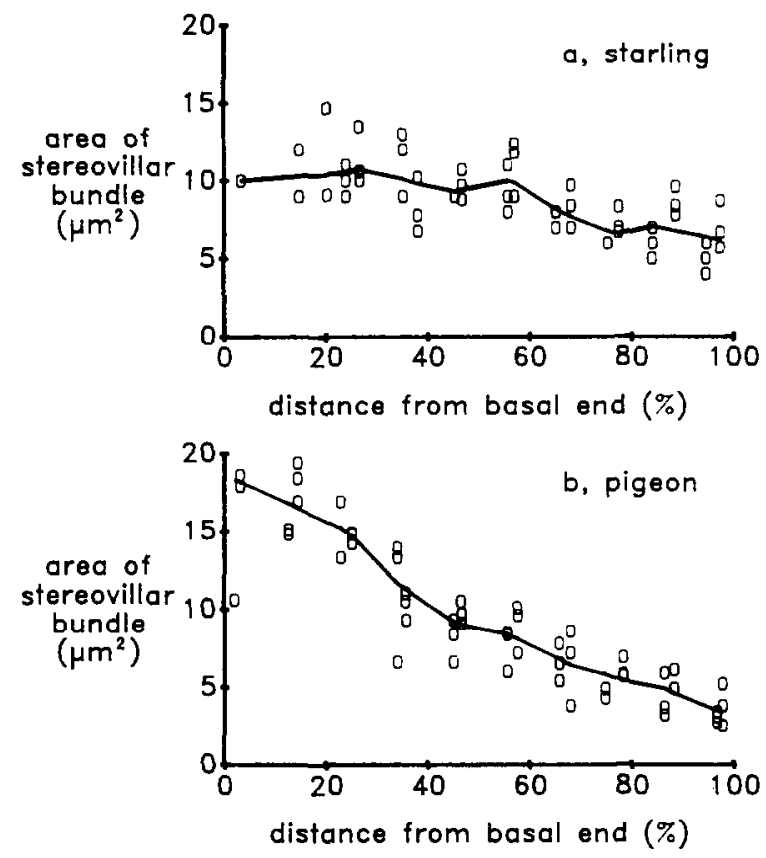

Fig. 7. The apical surface of a hair cell occupied by the base of the stereovillar bundle as a function of position on the basilar papilla. There is only a slight decrease from the base to the apex in the starling (a), but a much more pronounced decrease in the pigeon (b) (for linear regression of (a) $N=53, R=$ $-0.69, P<0.001$; for (b) $N=49, R=-0.90, P<0.001$ ). 


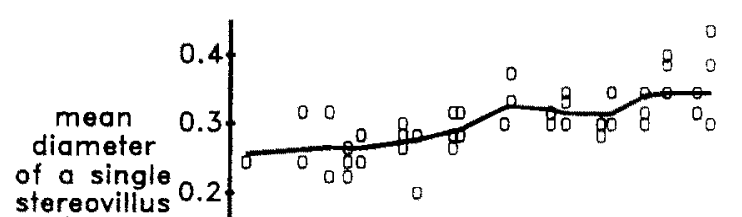

(um)
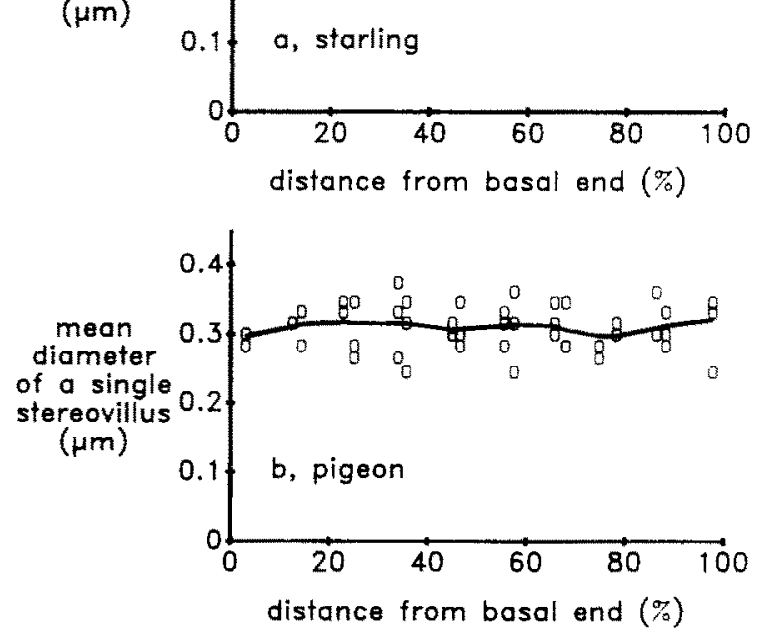

Fig. 8. The diameter of a single villus as a function of position on the papilla. In the starling (a) the diameter increases by about $50 \%$ from the base to the apex, whereas it is virtually constant over the length of the papilla in the pigeon (b) (for linear regression of (a) $N=53, R=-0.67, P<0.001$; for (b) $N-49, R-0.04, P>0.05$, not significant).
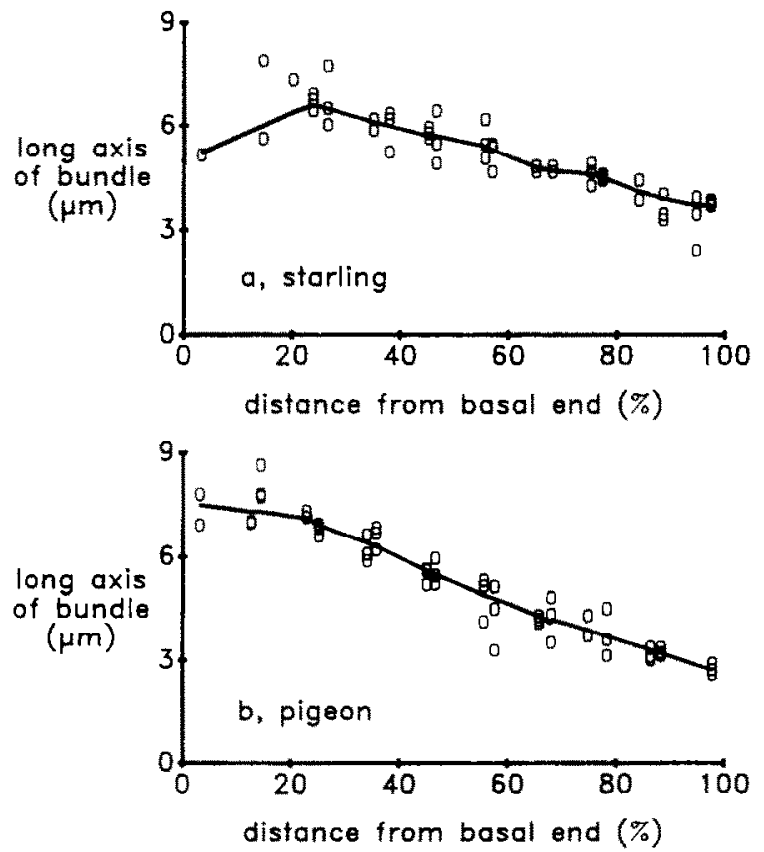

The height of the tallest villus within the stereovillar bundle was determined in one starling and one pigeon ear. Fig. 12 illustrates the villar height for 10 or 11 positions along the papilla (from the base to the apex). The position along the papilla is given as the distance from the apical end and not as a percentage of the basilar papilla length, as the twisting of the papilla in its basal third makes it difficult to determine the absolute position with respect to the basal end from serial sections. In the starling, the villar height increases from $2.7 \mu \mathrm{m}$ near the base to $9.4 \mu \mathrm{m}$ at the apex (average of all cells in one cross section; Fig. 12a) and from 4.0 in the basal third to 12.7 at the apical end in the pigeon (Fig. 12b). The fine line overlayed at each position shows the villar height for successive cells, in each case measured crossing the papilla from the neural (on the right in Fig. 12) to the abneural (left) side. Compared to the pigeon, there is no consistent systematic variation of villar height over the width of the starling papilla, although in both species the stereovilli of medially-lying cells are often shorter.

The hair cells in the avian papilla are systematically oriented, as defined either by the location of
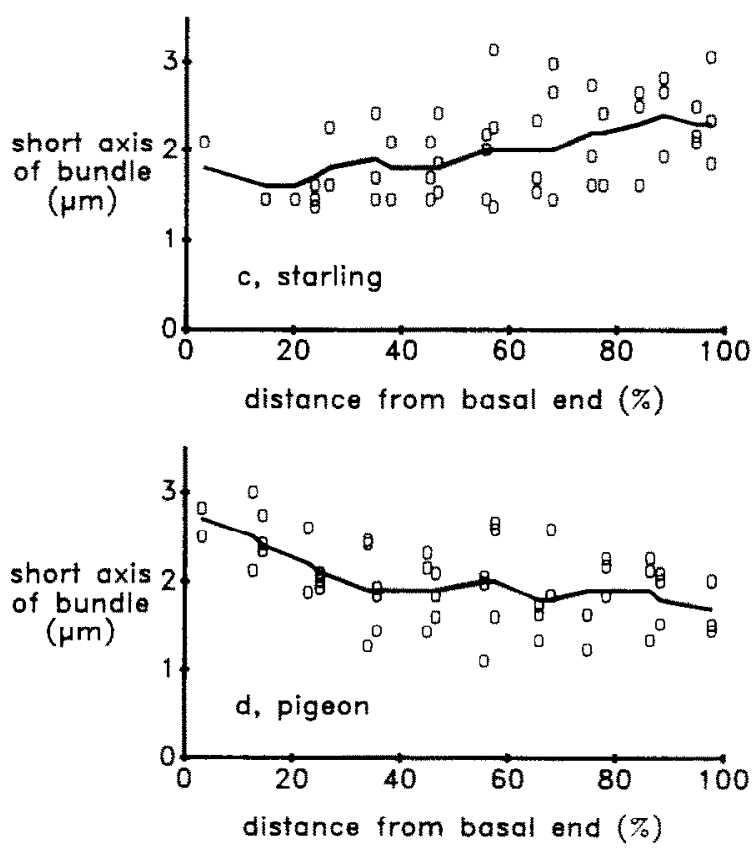

Fig. 9. The shape of the stereovillar bundle changes in a definite way over the length of the papilla. The long axis of the bundle decreases in starling (a) and pigeon (b) from the base to the apex. The short axis of the bundle increases slightly in the starling (c), but decreases in the pigeon (d) from the basal to the apical end (for linear regression of (a) $N=52, R=-0.87, P<0.001$; for (b) $N=50, R=-0.95, P<0.001$; for (c) $N=52, R=0.46, P<0.001$; for (d) $N=50, R=-0.44, P<0.01$ ). 

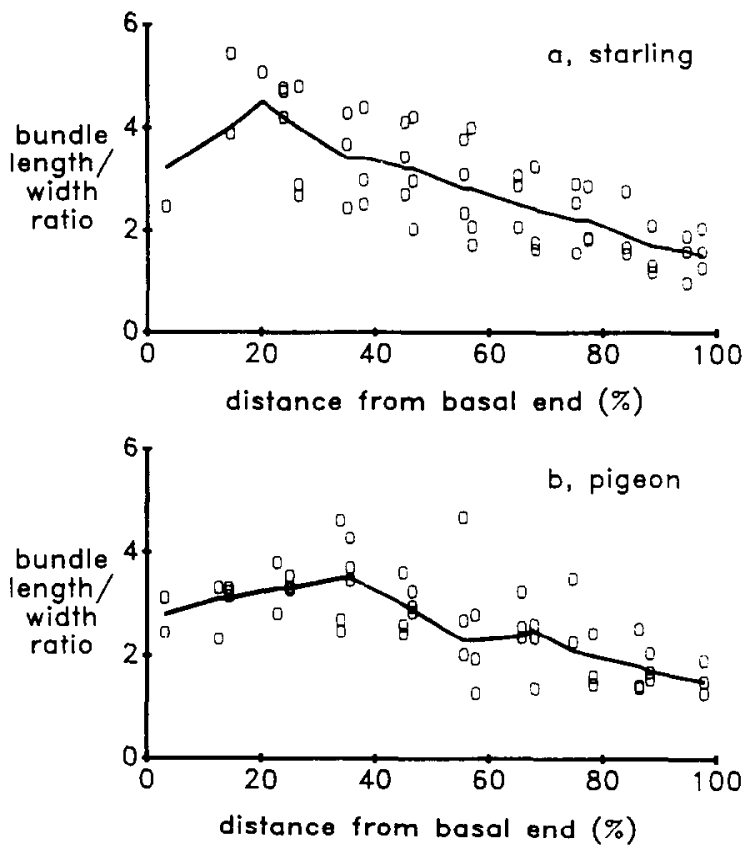

Fig. 10. Variation of bundle symmetry over the length of the papilla. The ratio of the bundle length to the width decreases in starlings (a) almost continuously from the base to the apex. In pigeons (b) the bundle symmetry seems almost constant in the basal third, and decreases only in the apical two thirds of the epithelium (for linear regression of (a) $N=52, R=-0.74$, $P<0.001$; for (b) $N=50, R=-0.61, P<0.001$ ).

the kinocilium (if preserved) or by the graded increase of the stereovillar height within one bundlc. The gradual change of hair-cell oricntation over the width of the basilar papilla is shown in Fig. 5 for a starling. Iso-orientation contours for the entire papilla describe the orientation pattern in detail. Apart from some individual variation, the global pattern is the same in the starling (Fig. 13a) and the pigeon (Fig. 13b) papilla. Over the whole papilla, hair cells located near the neural or abneural side are oriented abneurally $\left(0^{\circ}\right)$. Stereovillar hundles are gradually rotated towards the apex when crossing the papilla from the neural to the abneural side until a maximum (up to $90^{\circ}$ ) is reached in the mid-region of the epithelium. The orientation gradually rotates back when proceeding further to the abneural side. The maximum rotation of hair cells increases gradually from the base to the apex. The variation between individuals was mainly a difference in the absolute maxi- mum of rotation of orientation, which varied between $60^{\circ}$ and $90^{\circ}$.

We also investigated the most apical end of the starling and pigeon basilar papilla (Fig. 14), in order to see if the specializations described by Lavigne-Rebillard et al. (1985) for the chick are present in these species. However, we did not see the striking reduction of hair cell surface in connection with the increase of surface area occupied by the microvilli of the supporting cells, a change which was very obvious in the area of the chick papilla which they termed the VDP (very distal part). The apical end of the pigeon papilla, however, differs from that of the starling papilla not only in the width and number of hair cells in a cross-section. Whereas the cross-sectional area of the pigeon papilla near the apex is, as expected, roughly double that of the starling (Fig. 15a), the basilar membrane and tectorial membrane are disproportionately large (Fig. 15b, c). Although the cross-sectional area and thus the mass of the tec-
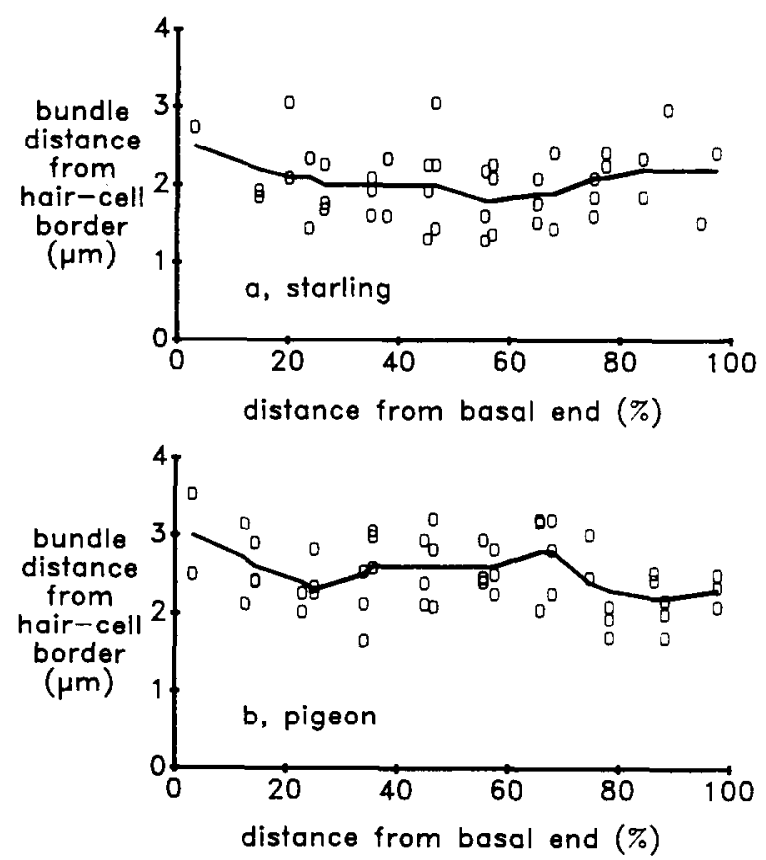

Fig. 11. The distance of the stereovillar bundle to the hair cell border over the length of the papilla. There is little variation over the length of the papilla, the mean value being $2 \pm 1 \mu \mathrm{m}$ in the starling (a) and $2.5 \pm 1 \mu \mathrm{m}$ in the pigeon (b) (for linear regression of (a) $N=45, R=-0.04, P>0.05$, not significant; for (b) $N=49, R=-0.24, P>0.05$, not significant). 

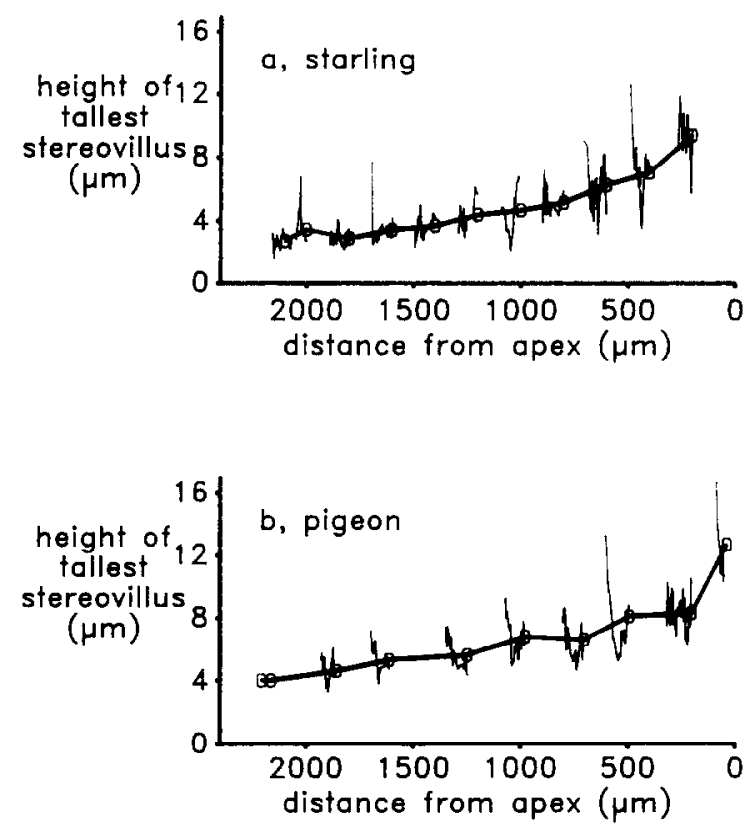

Fig. 12. The height of the tallest stereovilli was measured from cross sections through the cochlear duct, from neural to abneural. For 10 or 11 sections in each species, the average of all bundles measured within one cross section $(0)$ is plotted versus the distance of that section from the apical end of the papilla and connected by the heavy line. The set of fine lines to the left of the averaged points each connect the height of individual bundles measured when proceeding from the neural side of a single section (right) to the abneural side (left). These detailed measurements were not possible in the two most basal sections in the pigeon cochleae (b). The villar height increases from the base to the apex, without a consistent systematic gradient over the width of the papilla in starling (a) and pigeon (b). As the basal ends of both cochlea twist out of the plane of section, the data points are given as measured from the apical end.

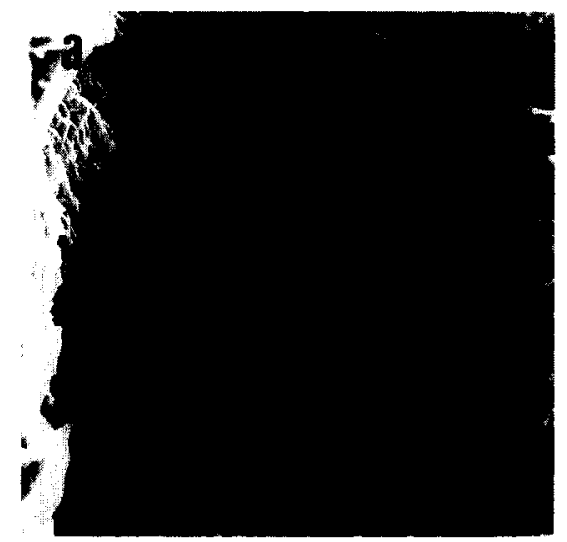

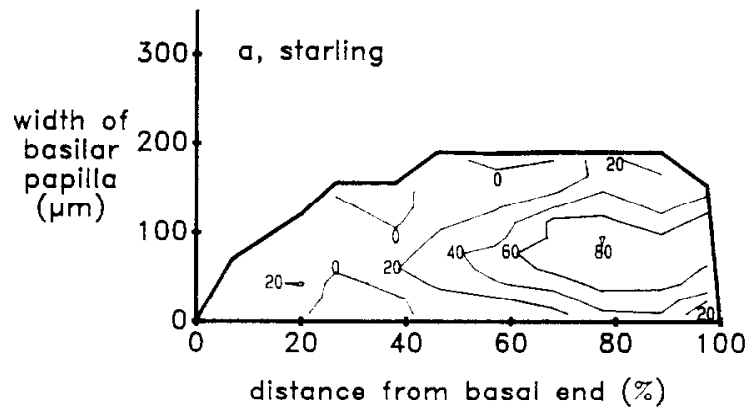

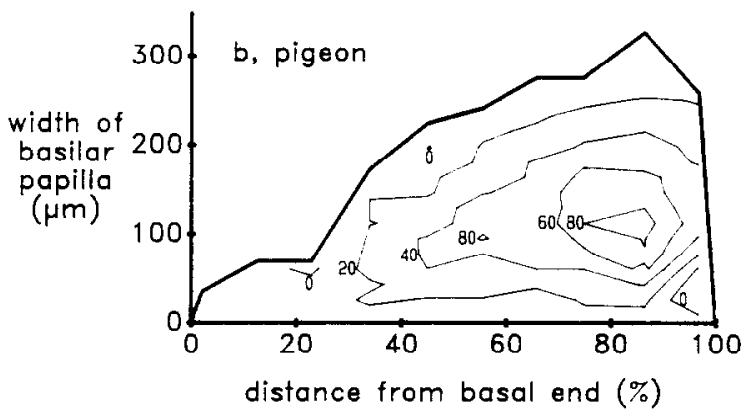

Fig. 13. Iso-orientation contours (for angles of $0^{\circ}, 20^{\circ}, 40^{\circ}$, $60^{\circ}$ and $80^{\circ}$ ) constructed from orientation profiles determined over the width at ten locations along the papillae (see Fig. 1a). These iso-orientation contours displayed an essentially identical pattern in all 4 specimens investigated. There is a gradual change in orientation over the width and over the length of the papilla. This is shown for one starling (a) and one pigeon (b). Hair cells near the neural and the abneural side are abneurally $\left(0^{\circ}-20^{\circ}\right)$ oriented, while those in more medial and apical regions are rotated towards the apex (up to $90^{\circ}$ ).

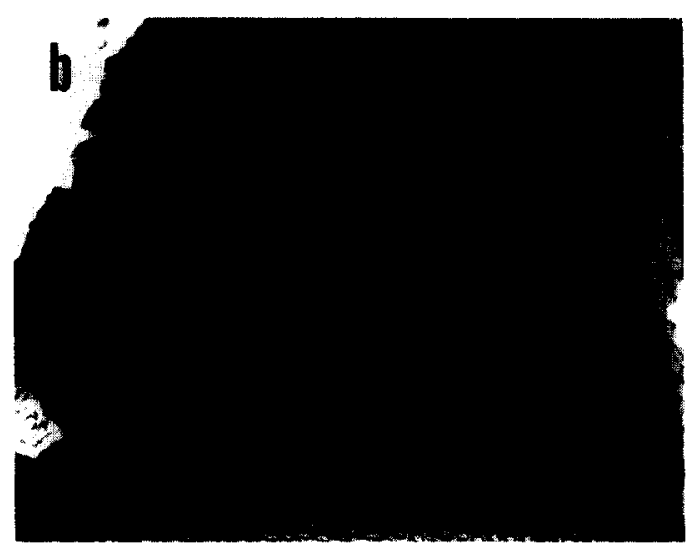

Fig. 14. Photomicrographs of the most apical end of a starling (a) and pigeon (b) basilar papilla, with the neural end oriented to the left. Despite the somewhat irregular outline of the pigeon papilla, there are no obvious specializations of the papilla or the hair cells (i.e., the hair cell surface area is not reduced and the area occupied by the microvilli of the supporting cells is not increased compared to more basal parts of the papilla; calibration bar corresponds to $100 \mu \mathrm{m}$ ). 

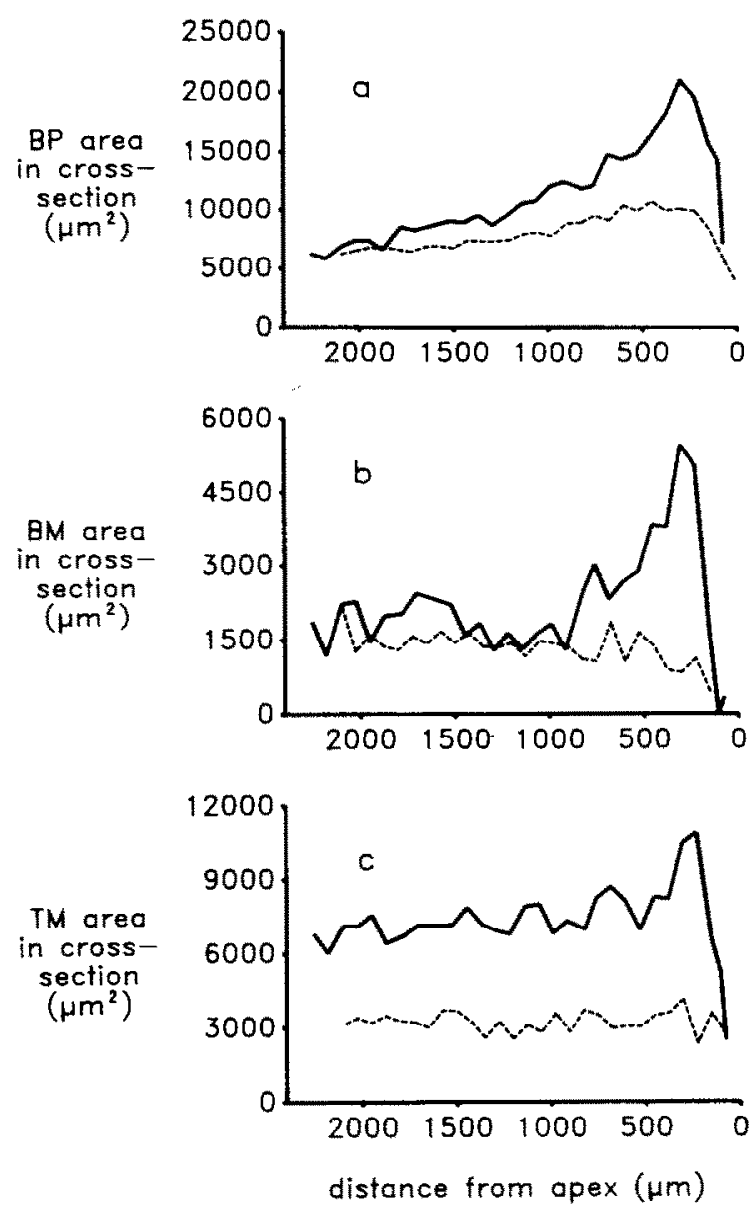

Fig. 15. Area in cross-section of the basilar papilla (a), basilar membrane (b) and tectorial membrane (c) of pigeon (heavy continuous line) and starling (dashed line) as a function of the distance from the apical end of the papilla. For ease of comparison with other figures, the abscissa has been plotted reversed.

torial membrane in the pigeon is greater than that of the starling throughout the papilla, it shows an additional increase in the apical area (Fig. 15c). The basilar membrane, in contrast, has essentially the same area as in the starling basally but increases almost five-fold in the apical area. Here, the area of the starling basilar membrane is decreasing (Fig. 15b). The basilar membrane of the pigeon is not only wider apically, it is also substantially thicker. Taken together, these data indicate that the mechanical factors affecting the frequency response of the apex of the pigeon cochlea are quite different to those of the starling.

\section{Discussion}

In the past, the attempt to make general statements from a small data base has led to an incorrect conception of some important features of the fine morphology of the bird's Papilla basilaris. We point out below some of the inconsistencies in the literature and present a more consistent picture of the morphological patterns on the bird basilar papilla, which emerges from a comparison of the present results with newer data from the chick and the owl.

The length of the basilar papilla depends not only on the species under investigation, but also, as shown in Table I, on the method used to determine the length. It is thus extremely important in making comparisons between species to take the artefacts of different histological procedures into account. Our measurement of the length of the basilar papilla in the pigeon is smaller than reported by Schwartzkopff and Winter (1960), Rosenhall (1971), Takasaka and Smith (1971) and Boord (1969). Our value for the starling is also shorter than that given by Düring et al. (1985). Also, the chicken and budgerigar papillae we measured are at the lower end of the values previously published for these species (see Table I). These discrepancies originate from different sources. Takasaka and Smith (1971) state that it is difficult to measure the length of the basilar papilla from serial sections because of the curvature of the basal end. Our data also indicate individual variation in the papillar length; this variation is greater in pigeons than in starlings. However, the most important source of the difference is the fact that our specimens were critical-point dried, which causes substantial shrinkage of the tissue $(29 \%$ as compared to the length of whole mounts of starling papillae in methyl salicylate). Assuming the same shrinkage for our pigeon, chicken and budgerigar papillae, we can estimate that the specimens were $4.03 \mathrm{~mm}, 4.73 \mathrm{~mm}$ and $2.60 \mathrm{~mm}$ long before drying, which is very similar to previously-published data. Thus in general, measures obtained using SEM are shorter than those from serial sections or whole mounts (see Table I).

Shrinkage is also introduced by fixation and dehydration of the specimens. This is obvious from Table I, as the values given by Schwartz- 
TABLE 1

THE TABLE COMPARES A NUMBER OF BASILAR PAPILLA FEATURES FOUND IN A VARIETY OF BIRD SPECIES

\begin{tabular}{|c|c|c|c|c|c|c|}
\hline \multirow[t]{2}{*}{ Species } & \multirow{2}{*}{$\begin{array}{l}\text { Basilar } \\
\text { papilla } \\
\text { length }(\mathrm{mm})\end{array}$} & \multirow{2}{*}{$\begin{array}{l}\text { Investigation } \\
\text { technique }\end{array}$} & \multirow{2}{*}{$\begin{array}{l}\text { Number of } \\
\text { hair cells }\end{array}$} & \multicolumn{2}{|c|}{ Number of stereovilli } & \multirow[t]{2}{*}{ Source } \\
\hline & & & & basal & apical & \\
\hline barn owl & $8.7-9$ & SEM & 16300 & $165-190$ & 50 & (Fischer et al., in prep.) \\
\hline barn owl & $9.5-11.5$ & sections & & & & (Smith et al., 1985) \\
\hline barn owl & 10.75 & whole $\mathrm{m}$. & & & & (Schwartzkopff and Winter, 1960) \\
\hline long eared owl & 11 & - & 14780 & & & (Düring et al., 1983) \\
\hline budgerigar & 2.02 & SEM & & & & (this study) \\
\hline budgerigar & 2.3 & sections & & & & (Smith, 1981) \\
\hline budgerigar & 2.45 & whole $\mathrm{m}$. & & & & (Schwartzkopff and Winter, 1960) \\
\hline buzzard & 3.45 & whole $\mathrm{m}$. & & & & (Schwartzkopff and Winter, 1960) \\
\hline chicken & & & 10400 & & & (Tilney and Tilney, 1986) \\
\hline chicken & 3.1 & SEM & $\approx 5000$ & 300 & 50 & (Tilney and Saunders, 1983) \\
\hline chicken & 3.5 & & & & & (Hirokawa, 1978) \\
\hline chicken & 3.67 & SEM & & & & (this study) \\
\hline chicken & 4.43 & sections & & $160-170$ & $50-65$ & (Tanaka and Smith, 1978) \\
\hline chicken & 5.83 & whole m. & & & & (Békésy, 1944) \\
\hline chicken & 6 & - & 11140 & & & (Düring et al., 1983) \\
\hline duck & 3.0 & - & & & & (Chandler, 1984) \\
\hline pigeon & & & 10400 & & & (Goodley and Boord, 1966) \\
\hline pigeon & 3.13 & SEM & 9610 & 200 & 50 & (this study) \\
\hline pigeon & 3.74 & - & & & & (Boord, 1969) \\
\hline pigeon & 3.8 & sections & & $120-150$ & $65-75$ & (Takasaka and Smith, 1971) \\
\hline pigeon & 4 & whole m. & 9610 & & & (Rosenhall, 1971) \\
\hline pigeon & 4.45 & whole $\mathrm{m}$. & & & & (Schwartzkopff and Winter, 1960) \\
\hline seagull & 2.4 & SEM & & & & (Counter and Tsao, 1986) \\
\hline shearwater & 4 & - & 3830 & & & (Düring et al., 1983) \\
\hline blackbird & 2.35 & whole $\mathrm{m}$. & & & & (Schwartzkopff and Winter, 1960) \\
\hline jay & 3.85 & whole $\mathrm{m}$. & & & & (Schwartzkopff and Winter, 1960) \\
\hline pine sisken & 2.2 & sections & & & & (Smith, 1981) \\
\hline sparrow & 2.2 & sections & & & & (Smith, 1981) \\
\hline starling & 2.22 & SEM & 5830 & 200 & 50 & (this study) \\
\hline starling & 2.86 & whole m. & & & & (this study) \\
\hline starling & 4 & - & 5900 & & & (Düring et al, 1983) \\
\hline
\end{tabular}

The third column indicates the method used to determine the length of the basilar papilla. SEM = scanning electron microscope, sections stands for serial cross sections and whole $\mathrm{m}$. indicates that the length was measured from whole mounts.

kopff and Winter (1960) and Békésy (1944), who mainly studied fresh, unfixed cochleae, are generally at the upper limit of the values for a given species. In the starling, however, shrinkage is not sufficient to explain the large difference between our measurements and those reported by von Düring et al. (1985).

The number of hair cells also shows great variation between species (Table I). Our hair cell counts from starling and pigeon are in very good agreement with previous studies.

The basilar papilla in birds is narrow at the base and widens progressively towards the apex (see e.g., Fig. 2a). Although there is general agreement on this statement, different studies have produced a great variety of results for one species. A continuous increase of basilar papilla width is present in the starling $(0.04$ to $0.19 \mathrm{~mm})$, the chick ( 0.11 to $0.57 \mathrm{~mm}$, Hirokawa, 1978 , and 0 to 0.15 $\mathrm{mm}$, Tilney and Saunders, 1983), seagull (0.09 to $0.2 \mathrm{~mm}$, Counter and Tsao, 1986) and barn owl (0.045 to $0.24 \mathrm{~mm}$, Fischer et al., 1988). Smith et al. (1985) describe a sudden widening in the apical $15 \%$ of the owl basilar membrane. However, the basilar membrane cannot be directly compared to the basilar papilla. In contrast to the birds de- 
scribed above, the apical third of the pigeon papilla suddenly widens towards the apical end. Our value for the maximum width of $0.26 \mathrm{~mm}$ is less than the $0.4 \mathrm{~mm}$ reported by Boord (1969) and Rosenhall (1971). The differences within one species, as for the papillar length, are at least partly due to different preparation techniques.

The number of hair cells in a given cross-section increases from the basal to the apical end. This increase is continuous for the starling, from 8 to 32 cells (Fig. 3 ) and has a similar pattern to that reported for the chicken (5-45 cells, Hirokawa, 1978; 0-40 cells, Tilney and Saunders, 1983; 5-25, Ryals and Rubel, 1985). In the pigeon, in contrast, the hair cell number increases dramatically in the apical third of the papilla ( 9 to 48, Fig. 3b). Although Takasaka and Smith (1971) found a similar increase, they did not find the pronounced discontinuity in their sectioned material. The barn owl shows a third type of pattern; there is only a small increase of the hair cell number in a cross section in the basal half of the papilla, followed by a more rapid but continuous increase in the apical half (Fischer et al., 1988; Smith et al., 1985).

The apical surface area of the hair cells shows species-specific variation over the length and width of the basilar papilla. Tanaka and Smith (1978) report for the chicken that the variation of diameter (which is of course related to the surface area) is most pronounced in the middle of the papilla, where the diameter ranges from 5-7 $\mu \mathrm{m}$ for 'tall' to $18 \mu \mathrm{m}$ for 'short' hair cells. The starling, pigeon (Fig. 6) and chicken (Tilney and Saunders, 1983) share a similar pattern of the distribution of hair cell surface area on the papilla, whereas the owl has a completely different pattern (Fischer et al., 1988). Except in the owl, the surface area of hair cells located on the neural side of the epithelium is small and almost constant over the length of the papilla. In the other three species, in contrast, the surface area of abneurally-located hair cells at about $50 \%$ of the papillar length is about $2-3$ times larger than at the basal and apical end.

The number of stereovilli per hair cell is also a function of the position within the sensory epithelium (Table I). The values reported are rather uniform and resemble the pattern we describe for the starling and pigeon (Fig. 4). Cotanche and
Sulik (1984) report that in the chicken, this gradient is already developed by embryonic day 9 .

Systematic variation of stereovillar height is known to be correlated with the tonotopic organization of hair cells (e.g., in the alligator lizard, Holton and Hudspeth, 1983). Our data in the starling and the pigeon show an increase of stereovillar height from about $3 \mu \mathrm{m}$ near the base up to more than $10 \mu \mathrm{m}$ at the apex, without systematic variation over the width of the papilla (Fig. 12). For the shearwater, starling, chicken and the long-eared owl, von Düring et al. (1985) reported an increase of stereovillar height in a basal-apical direction. Similar gradients were reported for the duck ( $2 \mu \mathrm{m}$ to $8 \mu \mathrm{m}$; Chandler, 1984), the seagull ( 1 to $3 \mu \mathrm{m}$; Counter and Tsao, 1986) and chick (2.5 $\mu \mathrm{m}$ to $8 \mu \mathrm{m}$; Tanaka and Smith (1978).

Tilney and Saunders (1983) show in more detail the distribution of the stereovillar height along the chicken basilar papilla; it increases slightly from $1.5 \mu \mathrm{m}$ to $2 \mu \mathrm{m}$ within the basal third and then further to $5.3 \mu \mathrm{m}$ at the apex. This resembles the pattern we found in the starling. Tilney et al. (1987) report systematic gradients of the stereovillar height over the width of the chicken papilla. Stereovilli of 'tail' hair cells are longer than those of 'short' hair cells, such that iso-height contours run obliquely from basal-neural to apical-abneural. In the starling and more pronounced in the pigeon, the stereovilli of cells in the middle of the epithelium are shortest (Fig. 12). In the pigeon, and in contrast to the chicken, abneurally-lying hair cells have longer stereovilli than neurally-lying hair cells. The steady increase in stereovillar height over the length of the chicken epithelium as shown by Tilney et al. (1987) is in contrast to our results from starling and pigeon and, indeed, to those of Tilney and Saunders (1983) from the chick. There is a pronounced nonlinearity in the increase of stereovillar height, which is even more pronounced in the barn owl (uniformly $1.3 \mu \mathrm{m}$ in the basal half of the papilla and increasing to $5 \mu \mathrm{m}$ at the apical end; Fischer et al., 1988). Whereas the height of the tallest stereovilli is clearly an important parameter affecting the stiffness and thus the frequency response of stereovillar bundles, other parameters such as the number of stereovilli, shape of the bundle and mass of the tectorial membrane also need to be taken into account. 
That part of the surface of a hair cell occupied by the stereovillar bundle decreases only little in the starling but much more in the pigeon in a basal-apical direction (Fig. 7), independent of hair cell position across the width. The estimated diameter of a single villus in the pigeon is $0.3 \mu \mathrm{m}$ and is constant over the length of the papilla (Fig. $4 \mathrm{~b}$ and $7 \mathrm{~b}$ ). In starlings, the decrease of bundle surface is only half of that in pigeons (Fig. 7a), but the decrease of the number of stereovilli is similar (Fig. 4a); thus we found that the diameter of a single villus increases from $0.24 \mu \mathrm{m}$ at the base to $0.35 \mu \mathrm{m}$ at the apex. Fischer et al. (1988) report in the barn owl an increase of villar diameter from $0.34 \mu \mathrm{m}$ near the base to $0.65 \mu \mathrm{m}$ at the apex.

A significant gradient of villus diameter over the width of the papilla was not detected in these three species. The situation in the chick is, however, more complicated; 'tall' hair cells have very thin stereovilli with a constant diameter of 0.12 $\mu \mathrm{m}$ over the length of the papilla, but the diameter of 'short' hair cell villi decreases from $0.19 \mu \mathrm{m}$ near the base to $0.12 \mu \mathrm{m}$ at the apex (Tilney and Saunders, 1983). The stereovilli in the chick are thus very thin compared to those of other species. However, these data are not fully comparable, as these authors only measured the diameter of the tallest villi in each bundle.

The shape of the stereovillar bundle in birds differs from that of mammals (Lim, 1986). We have shown that the symmetry of the bundles (ratio of length to width of a bundle) changes gradually over the length of the starling and pigeon papilla (Fig. 10). However, the magnitude of the ratios and thus the asymmetry tend to be most pronounced in the owl (Fischer et al., 1988) and least in the pigeon. Tilney and Saunders (1983) studied the organization of the bundles in detail and report that the length of the bundles decreases from the base to the apex, while the width of the bundle is fairly constant for all hair cells. We measured these parameters (Fig. 9) and also found a clear continuous decrease of the length of the bundle from the base to the apex. However, the width of the bundles shows small, but significant changes $(P<0.01)$ over the length of the papilla. In starlings, the width of the bundle increases and in pigeons it decreases from the base to the apex.
Tilney and Saunders (1983) found 7 to 8 rows of stereovilli along the short axis of the bundle in all hair cells, independent of their longitudinal position and suggest that the additional villi of basally-located hair cells cause the increase of the bundle's long axis. This finding, together with changes in villar diameter, explains the similarity of the decrease of stereovillar number (per hair cell) and of the length of the bundle from the base to the apex in starling, pigeon (Fig. 4 and Fig. 9) and barn owl (Fischer et al., 1988).

In the chicken and owl, Tanaka and Smith (1978) and Smith et al. (1985) describe a special type of 'short' hair cell, the 'lenticular' hair cell. These 'lenticular' hair cells (a few in the chicken and many in the owl) have a feature which allows them to be recognized in the SEM - their stereovillar bundle is closer to the neural edge of the hair cell than to the abneural edge. Fischer et al. (1988) did not find a clearly-defined population of 'lenticular' hair cells in the barn owl, but rather a continuum. In the starling and pigeon, we found the distance of the bundle to the cell border (in the direction of cell polarization) to be fairly constant over the whole papilla $(2 \pm 1 \mu \mathrm{m}$ and $2.5 \pm 1 \mu \mathrm{m}$, respectively). This constant distance from the cell border means that in cells with a comparatively small surface, the bundle lies more centrally than in those with a large surface and that no lenticular cells were found. Thus, bundles of abneurally-located hair cells at about $50 \%$ of the papillar length are most eccentrically located.

Vertebrate hair cells are highly polarized; they are depolarized by bending the bundle towards the kinocilium or basal body and hyperpolarized by bending in the other direction (Hudspeth and Jacobs, 1979). Previous reports by Rosenhall (1971), Takasaka and Smith (1971) and Tanaka and Smith (1978) describe hair-cell orientation almost perpendicular to the long axis in the pigeon and chick papilla. They mention a slightly twisted orientation in the most apical portion of the papilla or a small number of hair cells at the apical tip with opposite polarity. Lavigne-Rebillard et al. (1985) describe a specialized region in the most apical end of the chicken papilla wherc the hair cells in the middle have their orientation shifted by about $90^{\circ}$ relative to 'tall' hair cells.

These descriptions differ significantly from our 
results for the starling and pigeon, as well as from the data presented by Tilney and Saunders (1983) and Tilney et al. (1987) for the chick and those of Fischer et al. (1988) for the owl. All the latter reports demonstrate substantial systematic variation of hair-cell orientation on the basilar papilla. As in the chick and the owl, we find that centrally-lying cells in the apical half of the papilla of the pigeon and starling (Fig. 13) are turned towards the apex by up to $90^{\circ}$. Tilney and Saunders (1983) report a gradual twist of the bundle orientation; bundles at the neural and abneural ends are oriented perpendicularly and twist gradually until an angle of $45^{\circ}$ is reached in the middle of the papilla. From Fig. 4a of Tilney et al. (1987), it can be estimated that centrally-located hair cells in the apical half of the papilla are oriented almost $90^{\circ}$ towards the apex. The orientation pattern in the owl shows more rapid transitions between $0^{\circ}$ and $50^{\circ}$ orientation (Fischer et al., 1988), which are partly related in position to the underlying edge of the free basilar membrane. Thus the orientation patterns may be an adaptation (whose functional significance is as yet obscure) to the fact that only part of the hair-cell mosaic is found over the free basilar membrane.

Tilney et al. (1987) suggest that the pattern of mechanical stimulation of the avian papilla follows oblique lines across the papilla, following cells with equally-long stereovillar bundles. However, as we did not find similar iso-height contours, this suggestion would be difficult to reconcile with the iso-orientation contours we describe (Fig. 13).

The aim of this study is to contribute to a synthesis between structure and function of the avian cochlea. The comparison of our results and previous reports reveals a number of common features of the basilar papilla anatomy between the species studied, but also some pronounced differences. Some features of a 'typical' avian basilar papilla are as follows:

- it is relatively short, less than $5 \mathrm{~mm}$;

- there is a gradual widening from the base to the apex;

- there is a gradual increase of the number of hair cells in one cross-section from the base to the apex;
- the number of stereovilli per cell decreases from roughly 200 at the base to. 50 at the apex;

- the stereovillar height increases from 1-2 $\mu \mathrm{m}$ at the base to $5-12 \mu \mathrm{m}$ at the apex;

- the hair-cell surface is relatively small and almost constant over the length of the papilla on the neural side of the epithelium, while the hair-cell surface at the abneural side at about $50 \%$ of the papillar length is increased;

- there is a systematic pattern of hair-cell orientation with hair cells at the neural and the abneural side of the epithelium oriented perpendicular to the long axis and those between in the apical half gradually twisted up to $90^{\circ}$ towards the apex.

Striking deviations from this general pattern in a given species should be reflected in the auditory performance if the respective structures contribute significantly to the function. Specializations at the apical end of the papilla are found in the pigeon (excessive widening due to increase in number of hair cells in a transect, thickening of the tectorial and basilar membranes) and the chicken (Lavigne-Rebillard et al., 1985). There are reports of infrasound perception in the pigeon (Kreithen and Quine, 1979; Klinke and Schermuly, 1986) and chicken (Warchol and Dallos, 1987). In the pigeon papilla, cells receptive for infrasound appear to be abneurally-lying apical hair cells (Klinke and Schermuly, 1986). Considering the known tonotopic organization of the papilla of the chicken and starling (Gleich and Manley, 1988 Manley et al., 1987; Rubel and Ryals, 1983) these findings indicate a morphological specialization of the apical end of at least avian papillae for the reception of extremely low sound frequencies by abneural hair cells which apparently co-exist with neurally-lying cells responding to 'normal' low frequencies.

The barn owl papilla is not only longer but displays differences in several other aspects from the 'standard' bird papilla (Fischer et al., 1988); the patterns in the basal half of the papilla are different. The distinctive features described above may be assumed to be indicative of a functional specialization of the basal end of the barn owl's papilla with respect to its extended high frequency hearing range and extreme sensitivity (Konishi, 1973), as compared to other birds (Manley et al., 
1985; Sachs et al., 1978; Konishi, 1970).

We did not attempt in this report to distinguish between 'tall', 'intermediate' and 'short' (Takasaka and Smith, 1971) or 'inner' and 'outer' (Düring et al., 1985) hair cells. This distinction is not possible from a surface view, since these cell types have been defined using the form as seen in transverse section and the innervation pattern. Rosenhall (1971), Takasaka and Smith (1971), Smith (1981) and Düring et al. (1985) point out, however, that there is no absolute distinction between these groups of cells according to the arbitrarily-chosen criteria; they simply form a convenient way of describing the patterns in the papilla. All parameters we measured in the SEM changed gradually along and across the papilla.

Clear physiological data are necessary to assess whether several functional classes of hair cells exist. Recent studies in which physiologicallycharacterized primary afferent fibres were labelled and traced to hair cells indicate that they contact almost exclusively 'tall' hair cells (Manley et al., 1987; Gleich and Manley, 1988). This is a puzzling finding, for in the barn owl, with its excellent high frequency hearing, there are no 'tall' hair cells in the basal half of the papilla (Smith et al., 1985). However, these mapping data do suggest that there is a functional parallel between inner and outer hair cells of mammals on the one hand and tall and short hair cells on the other hand, despite their independent evolution (Manley et al., 1988).

It is obvious that the questions related to structure-function relationships need extensive further study.

\section{Acknowledgements}

We thank Birgit Seibel who carried out most of the painstaking measurements and made the photographic reconstructions. Thanks are also due to Udo Häusler for the surface measuring program, Britta Böhm for carrying out the measurements of cross-sectional surface areas and to Josef Gulden and Willi Maile for making possible the measurements of stereovillar height. F.P. Fischer, C. Köppl, H. Oeckinghaus and G. Yates made helpful comments on an earlier version of the manuscript. This work was supported by a grant from the Deutsche Forschungsgemeinschaft to
G.A.M. within the program of the Sonderforschungsbereich 204 'Gehör'.

\section{References}

Békésy G. von (1944) Über die mechanische Frequenzanalyse in der Schnecke verschiedener Tiere. Akust. Z. 9, 3-11.

Boord R.L. (1969) The anatomy of the avian auditory system. Ann. New York Acad. Sci. 167, 186-198.

Chandler J.P. (1984) Light and electron microscopic studies of the basilar papilla in the duck Anas platyrhynchos. I. The hatchling. J. Comp. Neurol. 222, 506-522.

Cleveland W.S. (1979) Robust locally weighted regression and smoothing scatterplots. J. Am. Stat. Ass. 74, 829-836.

Cotanche D.A. and Sulik K.K. (1984) The development of stereociliary bundles in the cochlear duct of chick embryos. Develop. Brain Res. 16, 181-193.

Counter S.A. and Tsao P. (1986) Morphology of the seagull's inner ear. Acta Otolaryngol. 101, 34-42.

Düring M. von, Andres K.H. and Simon K. (1985) The comparative anatomy of the basilar papillae in birds. Fortschritte der Zoologie 30, 681-685.

Firbas W. and Müller G. (1983) The efferent innervation of the avian cochlea. Hear. Res. 10, 109-116.

Fischer F.P., Köppl C. and Manley G.A. (1988) The basilar papilla of the barn owl Tyto alba: A quantitative morphological SEM analysis. Hear. Res. 34, 87-102.

Gleich O. and Manley G.A. (1988) Synaptic input of primary auditory afferent in the startling. Abst. Eleventh ARO Res. Meet. 238-239.

Goodley L.B. and Boord R.L. (1966) Quantitative analysis of the hair cells of the auditory papilla of the pigeon. Am. Zool. 6, 542.

Held H. (1926) Die Cochlea der Säuger und der Vögel, ihre Entwicklung und ihr Bau. In: A. Bette, G. v. Bergmann, G. Embden and A. Ellinger (Eds.), Handbuch der normalen und pathologischen Physiologie mit Berücksichtigung der experimentellen Pharmakologie, Springer-Verlag, Berlin, New York, pp. 467-534.

Hirokawa N. (1978) The ultrastructure of the basilar papilla of the chick. J. Comp. Neurol. 181, 361-374.

Holton T. and Hudspeth A.J. (1983) A micromechanical contribution to cochlear tuning and tonotopic organization. Science 222, 508-510.

Hudspeth A.J. and Jacobs R. (1979) Stereocilia mediate transduction in vertebrate hair cells. Proc. Natl. Acad. Sci. U.S.A. 76, 1506-1509.

Klinke R. and Schermuly L. (1986) Inner ear mechanics of the crocodilian and avian basilar papillae in comparison to neuronal data. Hear. Res. 22, 183-184.

Konishi M. (1970) Comparative neurophysiological studies of hearing and vocalizations in songbirds. Z. Vergl. Physiol. 66, 257-272.

Konishi M. (1973) How the owl tracks its prey. Am. Sci. 61, 414-424.

Kreithen M.L. and Quine D.B. (1979) Infrasound detection by 
the homing pigeon: a behavioural audiogram. J. Comp. Physiol. 129, 1-4.

Lavigne-Rebillard M., Cousillas H. and Pujol R. (1985) The very distal part of the basilar papilla in the chicken: a morphological approach. J. Comp. Neurol. 238, 340-347.

Lim D.J. (1986) Functional structure of the organ of Corti: a review. Hear. Res. 22, 117-146.

Manley G.A., Gleich O., Leppelsack H.-J. and Oeckinghaus H. (1985) Activity patterns of cochlear ganglion neurones in the starling. J. Comp. Physiol. A 157, 161-181.

Manley G.A., Brix J. and Kaiser A. (1987) Developmental stability of the tonotopic organization of the chick's basilar papilla. Science 237, 655-656.

Manley G.A., Brix J., Gleich O., Kaiser A., Köppl C. and Yates G. (1988) New aspects of comparative peripheral auditory physiology. In: Syka, J. (Ed.), Auditory System Structure and Function. Plenum Press, London, N.Y. in press.

Retzius G. (1884) Das Gehörorgan der Wirbelthiere. II. Das Gehörorgan der Reptilien, der Vögel und der Säugethiere. Samson and Wallin, Stockholm.

Rosenhall U. (1971) Morphological patterns of the organ of Corti in birds. Arch. Otorhinolaryngol. 200, 43-63.

Rubel E.W. and Ryals, B.M. (1983) Development of the place principle: acoustic trauma. Science 219, 512-514.

Ryals B.M. and Rubel E.W. (1985) Ontogenetic changes in the position of hair cell loss after acoustic overstimulation in the avian basilar papilla. Hear. Res. 19, 135-142.

Sachs M.B., Sinnot J.M. and Hienz R.D. (1978) Behavioural and physiological studies of hearing in birds. Fed. Proc. 37, 2329-2335.
Schwartzkopff J. and Winter P. (1960) Zur Anatomie der Vogel-Cochlea unter natürlichen Bedingungen. Biologisches Zentralblatt 79, 607-625.

Smith C.A. (1981) Recent advances in structural correlates of auditory receptors. In: D. Ottoson (Ed.), Progress in Sensory Physiology 2, Springer-Verlag, New York, pp. 135-187.

Smith C.A. (1985) Inner ear. In: A.S. King and J. McLeland (Eds.), Form and function in birds, Vol. 3, Acadenic Press, London, pp. 273-310.

Smith C.A., Konishi M. and Schuff N. (1985) Structure of the barn owl's (Tyto alba) inner ear. Hear. Res. 17, 237-247.

Takasaka T. and Smith C.A. (1971) The structure and innervation of the pigeon's basilar papilla. J. Ultrastruct. Res. 35, $20-65$.

Tanaka K. and Smith C.A. (1978) Structure of the chicken's inner ear. Am. J. Anat. 153, 251-271.

Tilney L.G. and Saunders J.C. (1983) Actin filaments, stereocilia, and hair cells of the bird cochlea. I. Length, number, width, and distribution of stereocilia of each hair cell are related to the position of the hair cell on the cochlea. J. Cell Biol. 96, 807-821.

Tilney L.G. and Tilney M.S. (1986) Functional organization of the cytoskeleton. Hear. Res. 22, 55-77.

Tilney M.S., Tilney L.G. and DeRosier D.J. (1987) The distribution of hair cell bundle lengths and orientations suggests an unexpected pattern of hair cell stimulation in the chick cochlea. Hear. Res. 25, 141-151.

Warchol M.E. and Dallos P. (1987) Single unit responses to very low frequency sound in the avian auditory brainstem. Abstr. Tenth ARO Res. Mig. 38-39. 